\title{
Information Literacy Primary School Students in the Czech Republic in International Comparison
}

\author{
PaedDr. Zuzana Horváthová, Ph. D. \\ Department of Law and Public Administration, Metropolitan University Prague \\ zuzana.horvathova@mup.cz
}

\author{
Assoc. Prof. Ing. Josef Abrhám, Ph. D. \\ Department of Law and Public Administration, Metropolitan University Prague \\ josef.abrham@mup.cz
}

\section{Doi:10.5901/jesr.2015.v5n1s1p103}

\begin{abstract}
Increasing amount of information available becomes a reality of the contemporary global world. However, proper and effective use of information depends on a set of information management skills. Recently, information literacy has become one of the key elements of the educational process at a primary, secondary and tertiary level. The aim of this paper is to evaluate the ability of primary school students to manage information. The main part of the research output is delivered via own survey, which focuses on final-year students of primary schools in the Czech Republic. Information sources, ability to select them and to make decision or trustworthiness check belong among those primarily examined. Also an access to new information and decision-making ability of students in selection process and use of information is analysed. The results of the survey are compared with those provided by academic literature and by other international research in this field.
\end{abstract}

Keywords: information literacy, basic education, Czech Republic, informatics and communication technology

\section{Introduction}

Information literacy has become an important prerequisite for successful processing in almost all fields of the current economy and society. The amount of available information continues to grow and increases the demand for the quality of its processing and handling. Thus information literacy has recently become in one of the essential parts of the educational process. Working with information in the educational process embodies itself in several ways. This is namely the ability of students to understand the text (literacy), skills in information and communication technologies including the internet and also the quality of the selection, classification and verification of information sources. Information skills are therefore subject to numerous research articles, various comparative studies at the international level as well as subject to methodologically oriented papers, which seeks to develop methods for measuring information literacy. This study represents a further contribution to the debate in the field.

The aim of this paper is to evaluate the ability of primary school students to manage information. The main part of the research output is delivered via own survey, which focuses on final-year students of primary schools in the Czech Republic. Information sources, ability to select them and to make decision or trustworthiness check belong among those primarily examined. Also an access to new information and decision-making ability of students in selection process and use of information is analysed. The results of the survey are compared with those provided by academic literature and by other international research in this field. The literature review also includes an overview of several methodological concepts of measurement information skills of students in primary and secondary schools, which were applied in the Czech Republic and the European Union.

\section{Theoretical Approaches to Education and Literacy in the Contemporary Information Society}

The increase in the importance of information literacy within the contemporary education and society is reflected in the academic papers that are covered in the following text. The emphasis is placed both on the assessment of the significance of information literacy in the works of theorists in the education field and also the different approaches to 
monitoring and evaluation of the information literacy.

On the basis of a research focusing on education and training in the information society, Dombrovská, Landová, Beneš and Rambousek came to the conclusion that although the educational potential of information technology opens up new possibilities for education in the information society, the approach of schools to the education has to be changed. If not, information technologies will not be a positive factor and will not make educational process more efficient, but rather they will only become a tool for upgrading the educational process, without its educational use in practice and continuing education (Beneš, Rambousek, 2005). The goal of modern education is a functional literacy and not the content of knowledge, as was the case in the past, which means interpretation and processing of not only statistical data (Dombrovská and Landová, 2004).

Fialová builds on the results of national research focused on students' opinions on the implementation of information technologies in education, where it was concluded that although information technology cannot replace the social interactions in the class and in the direct learning process, still with an appropriate use of computers (e. g. for a teamwork) pupils learn to work in a team and act as a single entity and thus the social conscience of individuals improves (Fialová, 2005).

Filipi defines information literacy as the ability to recognize the needs for information, the knowledge to find and use it effectively. He perceives this ability as a summary of skills to work with the most used software and internet use not only for communication but also for searching for and processing of information. ICT skills are seen as a unification and application of cognitive and technical skills and consist of five basic components, namely (Filipi, 2012, p. 11):

- Access: knowledge of gathering and getting the information via ICT;

- Manage: use of existing classification and organization scheme;

- Integrate: representation and interpretation of information via ICT;

- Evaluate: decision about relevance, usefulness, quality and efficiency of information;

- Create: creation of new own information, possibly using amendments and adjustments of the existing information via ICT.

Brdlička addressed the issue of integration of information education into curricula at primary and secondary schools. He understands the information education as a preparation for life in the information society where tutoring should not focus only on the computer but also on how to make appropriate use of this ability (Brdlička, 1998).

The trend in our modern society is using the internet, via computers one can easily and affordably communicate over long distances, seek information from diverse regions and sectors, to educate themselves, find jobs, work and shop. To make internet a benefit for individuals and not just a conduit for communication and spending leisure time by surfing or playing computer games, the pretty computer literacy is needed. In modern education the stress is put on children education in this area and from primary school these skills are taught. Adults are treated pretty same in this area as there is a necessity to have mastered at least basic skills related to the PC and ICT. The main reason is the competitiveness of individuals in the labour market, nowadays it is quite common that the given literacy is one of the requirements that are imposed on jobseekers by employers. The previous text shows that computer literacy is, together with functional literacy a part of the information literacy. An individual, who is not computer literate or functionally literate, can not necessarily be information literate. The relevant skills are necessary for current and future application and adaptation in the contemporary anamorphic society.

Mudrák considers the information education for a more cross-cutting discipline in many areas of education. That makes the discipline alone richer in terms of the content, ideology and also methodology, but at the same times that raises new questions and challenges to be addressed (e. g. the use of information technology in teaching physics, languages, mathematics and music). The concepts and relationships that show some stability in the dynamic environment of the information society must predominantly become the content of educational training. Finally, the didactics of information education should respect the cross-curricular nature (Mudrák, 2005).

In recent years, a number of projects have been implemented in the area of information literacy. They map literacy and work with information technologies in international comparison. One example of those studies is a study called the International Computer and Information Literacy Study, where the students of the 8th grade of the elementary schools and the students of the grammar schools at the corresponding grade are tested. The project focuses on the implementation of international research and the subsequent use of results in educational policy and their own teaching practice at schools in the country. In 2013, the undertaken research was aimed at detecting differences in computer and information literacy of students in the surveyed countries, at verifying the relationship between the success of students and educational systems setting, at the effect of technological background of the students on their success in computer and information literacy as well as at the effects of socio-economic background of students on their results in computer 
and information literacy (Fraillon, 2013).

Another example of a widespread concept in the area of computer literacy and skills is a so called European Computer Driving Licence (ECDL), which includes a wide range of training and certification programs. ECDL is internationally recognized certificate of computer literacy. The contents of the tests are based on the ECDL syllabus. They are subject to scrutiny of the sole proprietor of the ECDL concept and of the testing methodology, which is a nonprofit organization called Council of European Professional Informatics Societies (CEPIS). ECDL concept focuses on the labour market. The attention is paid to the successful and effective use of digital technologies (Neumajer, 2012).

A highly respected international comparative study is regularly published by OECD, so called PISA testing. This project focuses on mathematics, science and reading but also digital skills. From 2015, the testing in all areas surveyed runs electronically. As the most important skill of electronic reading is considered the orientation on sites which means quick browsing of the structure on non-linearly arranged websites. The students who did better managed to do so because they used a better strategy such as minimizing the visits of the irrelevant sites and vice versa finding quickly the requested ones. Test mechanisms in the PISA study simulate real situations. A student has the opportunity to work with simulations of a simple web-browser, which can be accessed on the pre-web addresses, pages and entire sites (Neumajer, 2012).

In the Czech Republic there has been recently undertaken a survey under the GAPARD programme, which focuses strongly in the area of working with information, it means on "information literacy" as such, and that applies to students already in elementary schools and then applies throughout the whole life. A technical use of ICT as a tool is somewhat less important than its meaning: work with information, their acquisition, processing and transmission to others. At the top of such prepared sites there is a set of tasks, through which a student goes in the course of testing. There are several types of tasks. Most often it is about solving a closed task, which has four alternatives and in order to determine the correct response, finding the relevant information on the website is needed. This website has usually set a few pages linked with references. In other tasks there are open questions that require answers creation. An example of this task is to send an e-mail through a web form. Everything is still ongoing in a simulated environment of the internet browser. The content of the e-mail should be a summary of information that can be found on the prepared site (Neumajer, 2012).

\section{The Research of Information Skills of Students in the Czech Republic}

The research is based on survey that focuses on identifying sources where fifteen year-old students of the Czech schools get their information. The emphasis is also placed on the ways of verifying the information and factors that influence the decision making of the students. The questionnaire was designed as a dialogue between the interviewer and the respondent. The questions were ordered from simple to more complex ones. They were closed with a choice of either one answers or marking on the range of options from a completely positive response to a negative one. Almost all the issues have been given the opportunity to answer "I do not know / I did not think about it. " The questionnaire was anonymous and the entire research was compiled on a sample of 470 respondents. The respondents were fifteen yearold students of secondary schools, grammar schools and apprenticeships from Prague and from the cities in the Central Bohemia. The questionnaire survey was carried out in the period from May to September 2014.

Based on the results of the survey seven answers to seven concrete questions will be discussed in the following text. These issues included the findings in the area of information sources, the information confrontation with the present level of knowledge, the assessment of decision-making skills of the students and the verification of the quality and relevance of the information.

Graph 1: Responses to the question „Where do you get most of your knowledge"

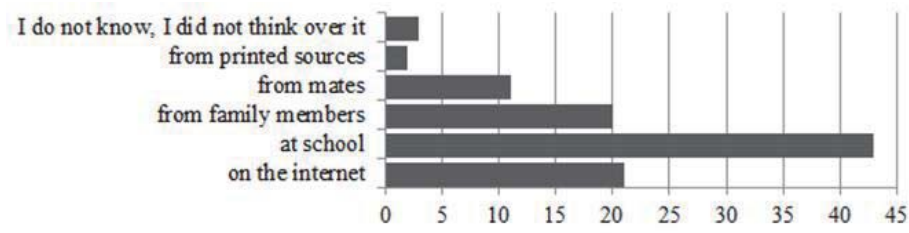

Source: Own survey made in 2014 
From Graph 1, which illustrates the responses to a question about sources of information, it is clear that most information students receive at school, followed by the options ",rom family members" and "on the internet“ which took almost the same position. In a much lesser extent students receive information from friends. The frequency of other offered options is negligible. Nearly half of the respondents use the educational process within the school as the main source of information. In contrast, almost a quarter of students stated that they obtained the knowledge on the internet and from individual family members. It can be therefore concluded that fewer than half of the students complete the compulsory education with the feeling that most of the knowledge provided to them was at school.

As for the second question, if they can confront the findings with their knowledge, the majority of respondents answered yes (Graph 2). The question was posed in order to investigate own opinion of the students on their ability to compare information and knowledge. The vast majority of students (97\%) think that they have this ability, however with varying degrees of intensity. The answer "hardly ever/never" was chosen only by $2 \%$ of students. The frequency of the response "I do not know" is only $1 \%$ and thus indicates a group of students who do not think over the information and knowledge. It can therefore be noted that the vast majority of students believe that they are able to process and compare the information obtained. On the other hand, it should be noted that such a positive response may be questionable, and it would be reasonable to complete the given survey with testing of the answers obtained.

Graph 2: Responses to the question „Are you able to confront the information with your existing knowledge? "

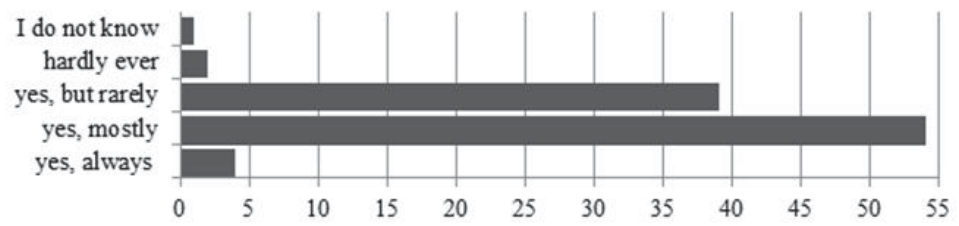

Source: Own survey made in 2014

Graph 3 shows the frequencies of the response to the question whether the respondents are aware of the need for their independent decision-making when working with information. Depending on their self-reflection based on their age, the students mostly answered positively. The vast majority of respondents (95\%) recognize the importance of decisionmaking, either "always" or "mostly" (more than 50\% of responses). The question was included in the survey on purpose as the conditions of the contemporary society place increasing demands on decision-making abilities of pupils and students (e. g. when choosing the next stage of education, study abroad, future occupation, etc. ).

Graph 3: Responses to the question "Are you aware of the need of own decision-making when working with the information?"

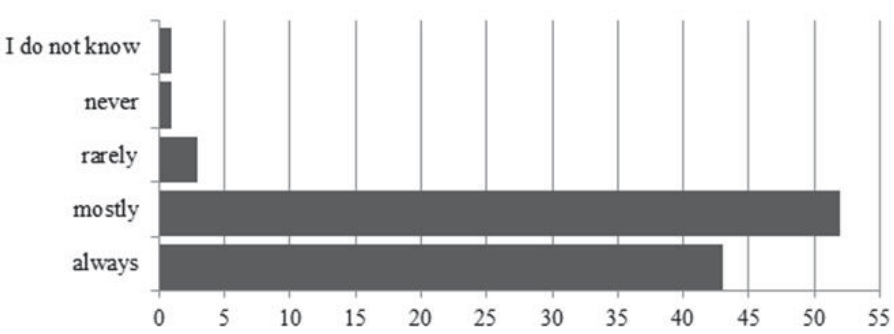

Source: Own survey made in 2014

In another area of the research, which involved the verification of the information obtained, the respondents were generally positive. Almost $90 \%$ of those surveyed verify the quality of information, especially when they have some doubts. Furthermore, the verification is also abundant in terms of knowledge which is exceptionally interesting. The negative range of responses is almost negligible. The question was asked as to determine whether and what information the students verify. The scale of answers offered was closed with a range from extremely positive to completely negative. 
Graph 4: Responses to the question „Do you verify the information obtained? "

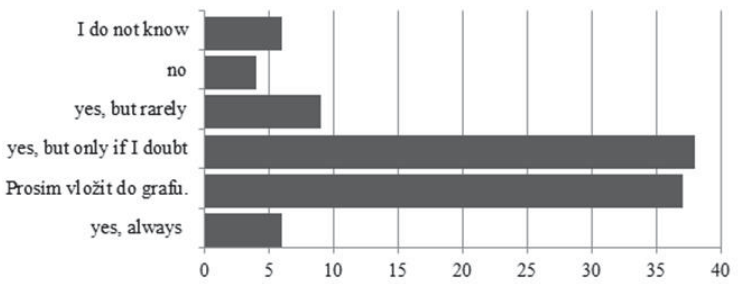

Source: Own survey made in 2014

Another question further elaborated the way of verifying information. Table 1 presents a simplified matrix in which we can read how (in what sources) and how often students verify the information. From Table 1 we can observe that the most preferred source is the internet. Also the trust in the family and in case of half of the students the trust in the school is positive. The role of other sources offered is entirely negligible. The questions included a closed range of answers indicating the frequency on the scale of the options from totally positive to the negative ones. There was also an option „I do not know" offered as the emergency one.

Table 1: Responses to the question "How often do students verify the information in the following sources?"

\begin{tabular}{|l|c|c|c|c|c|}
\hline & Often & Sometimes & Seldom & Not at all & I do not know \\
\hline At school & $10 \%$ & $40 \%$ & $35 \%$ & $5 \%$ & $10 \%$ \\
\hline At home & $40 \%$ & $42 \%$ & $13 \%$ & $3 \%$ & $2 \%$ \\
\hline On the internet (from one source) & $42 \%$ & $37 \%$ & $17 \%$ & $3 \%$ & $1 \%$ \\
\hline On the internet (from more sources) & $44 \%$ & $39 \%$ & $11 \%$ & $1 \%$ & $5 \%$ \\
\hline Combining more sources & $12 \%$ & $28 \%$ & $33 \%$ & $16 \%$ & $11 \%$ \\
\hline In daily press & $2 \%$ & $17 \%$ & $21 \%$ & $50 \%$ & $10 \%$ \\
\hline In books & $6 \%$ & $15 \%$ & $32 \%$ & $38 \%$ & $9 \%$ \\
\hline
\end{tabular}

Source: Own survey made in 2014

The last question of the questionnaire survey stems out from the hypothesis that the young man can be very easily influenced by the mass media, classmates and friends. A closed offer of the answers was compiled from the anticipated potential factors on the respondents at their age. Each answer offered contained a scale of the importance of the factors ranging from completely positive to completely negative. The answer „I do not know" was inserted as an emergency one, however, the frequency of that one was very low and thus not conclusive. The responses clearly showed that the major factors influencing students' decision-making are at first the benefit for a given student and then the information obtained. Another important factor is the view of the family, followed by the recommendation of teachers at school. The opinion of the friends and decision-making of the majority have only a partial effect. An actual mood has only a marginal effect.

Table 2: Responses to the question "Are students at this age influenced in their decision-making mainly by media and friends?"

\begin{tabular}{|l|c|c|c|c|c|}
\hline & Very important & Quite important & Not much important & Not important at all & I do not know \\
\hline TV, radio & $6 \%$ & $39 \%$ & $33 \%$ & $15 \%$ & $7 \%$ \\
\hline Opinion of friends & $13 \%$ & $44 \%$ & $38 \%$ & $4 \%$ & $1 \%$ \\
\hline Opinion of majority & $12 \%$ & $37 \%$ & $43 \%$ & $5 \%$ & $3 \%$ \\
\hline Recommendation of parents & $32 \%$ & $45 \%$ & $19 \%$ & $3 \%$ & $1 \%$ \\
\hline Recommendation of teachers & $27 \%$ & $46 \%$ & $23 \%$ & $2 \%$ & $2 \%$ \\
\hline Actual mood & $14 \%$ & $12 \%$ & $25 \%$ & $45 \%$ & $4 \%$ \\
\hline Personal benefit & $64 \%$ & $29 \%$ & $4 \%$ & $1 \%$ & $2 \%$ \\
\hline
\end{tabular}

Source: Own survey made in 2014 
The last question in the questionnaire featured the verification of the credibility of electronic information sources. It was assumed that the students consider the main sources of information those electronic ones. Internet sources are not only used to search for information, but also for self-education or spending leisure time by today's young generation (Table 3).

Table 3: Responses to the question „To what extent do the students trust the information sources? “

\begin{tabular}{|l|c|c|c|c|c|}
\hline & $\begin{array}{c}\text { Very } \\
\text { credible }\end{array}$ & $\begin{array}{c}\text { Quite } \\
\text { credible }\end{array}$ & $\begin{array}{c}\text { Not much } \\
\text { credible }\end{array}$ & Not credible at all & I do not know \\
\hline According to first offered sites by Google (or another viewer) & $16 \%$ & $53 \%$ & $23 \%$ & $5 \%$ & $3 \%$ \\
\hline Wikipedia & $33 \%$ & $44 \%$ & $18 \%$ & $4 \%$ & $1 \%$ \\
\hline Professional databases & $46 \%$ & $29 \%$ & $1 \%$ & $1 \%$ & $23 \%$ \\
\hline Academic websites & $39 \%$ & $25 \%$ & $11 \%$ & $4 \%$ & $21 \%$ \\
\hline Professional firms' websites & $26 \%$ & $34 \%$ & $10 \%$ & $8 \%$ & $22 \%$ \\
\hline
\end{tabular}

Source: Own survey made in 2014

The range of answers was once again closed and divided into a scale of two positive and two negative responses. The answer "I do not know" was re-launched as an emergency one. Since the aim of the question is to identify the views of respondents, the answer "I do not know" can be considered "I do not have that knowledge". The students probably do not know that source in the way that they do not use it. As "a very credible" information source were perceived technical or professional databases, followed by websites of academic institutions and professional firms. In contrast, the answer „I do not know" was the most frequent one with these sources. It can be therefore assumed that those who use these sources also trust them. However, almost a quarter of students probably do not know professional databases as a source of information, because they cannot assess their credibility. The information provided via Google and Wikipedia are considered by students predominantly as "more credible". However, with these sources, the answer "I do not know" emerged only in case of $3 \%$ of students. We can assume that students know these sources and perceive them as quite or very credible.

\section{Conclusion}

The importance of information literacy for the educational process as well as for other professional life of the graduates is confirmed both by the theoretical concepts as well as by strategic documents at national and international level. The importance of working with information is increasing as a result of the development of modern technology and the knowledge economy.

Based on the results of a questionnaire survey one can say that working with modern communication technologies and computers for students of elementary schools in the Czech Republic is quite natural. Mostly, students seek information on information portals, which are normally accessible both to users as well as to the authors who make up the content of the website etc. However, these sources are out of control in terms of truth and objectivity. If the students verify the information, they use the same sources for verification as for their acquisition. It can be assumed that they use the same internet sources in order to test their knowledge as the internet is the second most common source for obtaining knowledge right after the school.

The examined respondents used books, newspapers and magazines very marginally. The influence of the media such as television and radio is smaller than in the case of the internet. A very positive finding can be a still significant effect of family and school on obtaining and verifying information as well as on the subsequent decision-making. In this context, it seems appropriate to increase a focus of the educational process in the Czech Republic and other European Union countries on the information and communication technologies. School facilities must fully exploit the potential of new information sources and verify the ability to work with them on the side of their students. In relation to the undertaken research one may recommend the application of simulations of web browsers, testing the ability of electronic reading, the assessment of the speed of scrolling over non-linearly arranged structures of web sites, etc.

\section{References}

Beneš, P. , Rambousek, V. Výchova a vzdělávání v informační společnosti. In Vzdělávání pro život v informační společnosti. Praha: 
Pedagogická fakulta UK. 2005. s. 11. ISBN 80-7290-202-4.

Brdlička, B. Informační výchova na ZŠ z pohledu rodičů. Výsledky výzkumu mínění [online]. [cit. 20. 2. 2015]. Praha, 1998. Dostupné na: <http//it. pedf. cuni. cz>

Čajka, Rýsová, L. : Úloha univerzít v regionálnom rozvoji. In: Sborník z příspěvku z Mezinárodní geografické konference v Ostravě ve dnech 30. a 31. 8. 2004 „Geografie a proměny poznání geografické reality“, Ostrava: Ostravská univerzita v Ostravě, 2004 s. 377-382, ISBN 80-7042-788-4.

Černochová, M. , SIŇOR, S. Využití ICT ve školní praxi jako příprava na celoživotní učení v informační společnosti. In Vzdělávání pro život v informačni společnosti. Praha: Pedagogická fakulta UK. 2005. s. 301. ISBN 80-7290-202-4.

Dombrovská, M. ; Landová, H. ; Tichá, L. Informační gramotnost - teorie a praxe v ČR. Národní knihovna [online], 2004, roč. 15, č. 1, [cit. 2013-11-12]. Dostupný z WWW: http: //knihovna. nkp. cz/NKKR0401/0401007. html.

Fialová, I. Názory studentů kimplementaci informačních a komunikačních technologií do vzdělávání. In Vzdělávání pro život v informačni společnosti. Praha: Pedagogická fakulta UK. 2005. s. 377, 378. ISBN 80-7290-202-4.

Filipi, Z. Počítačová gramotnost a její zvyšování pomocí e-learningu u úředníků. In Information and Communication Technology in Education. Ostrava: University of Ostrava, 2010.

Fraillon, J. , Schulz, W. , Ainley, J. (2013). International Computer and Information Literacy Study: Assessment framework. Amsterdam: IEA.

Host'ovecký, M. , Mišut, M. , Pribilová, Web based testing in science education. In Lecture Notes in Electrical Engineering In Innovations and Advances in Computing, Informatics, Systems Sciences, Networking and Engineering, 2015, Springer International Publishing, ISBN 978-3-319-06772-8, pp. 247-254.

ICILS 2013 [online] Mezinárodní výzkum počitačové a informační gramotnosti, 2013, [2013-11-05]. Dostupný z WWW: http: //www. icils. $\mathrm{CZ}$.

Kleňhová, M. , Štastnová, P. , Cibulková, P. České školství v mezinárodním vzdělání. Praha: Ústav pro informace ve vzdělávání. 2010. ISBN 978-80-211-0604-8.

Kocourek, A. , Maršíková, K. Shifts in Income Expectations of Czech Students at Selected Economic Faculties over the Years 2001 2012. In Ekonomický časopis. 2013. roč. 61, č. 4, s. 358-375. ISSN 0013-3035.

Mudrák, D. Př́stupy k rozvoji didaktiky informační výchovy. In Vzděláváni pro život v informační společnosti. Praha: Pedagogická fakulta UK. 2005. s. 194. ISBN 80-7290-202-4.

Neumajer, O. Testování ICT dovedností v ČR - vybrané projekty a koncepty. Praha: Pedagogická fakulta UK. 2012.

Rubáček, F. Porovnání př́stupnosti webových prezentací středních škol v České a Slovenské republice. In Technológia vzdelávania. 2011. ISSN 1338-1202. 
ISSN 2239-978X

ISSN 2240-0524
Journal of Educational and Social Research MCSER Publishing, Rome-Italy
Vol. 5 No.1 S1 April 2015 